\title{
Neuroimmunology of the Interleukins 13 and 4
}

\author{
Simone Mori ${ }^{1}$, Pamela Maher ${ }^{2}$ and Bruno Conti ${ }^{1, *}$ \\ 1 Department of Chemical Physiology, The Scripps Research Institute, 10550 North Torrey Pines Road, \\ La Jolla, CA 92037, USA; smori@scripps.edu \\ 2 Cellular Neurobiology Laboratory, Salk Research Institute, La Jolla, CA 92037, USA; pmaher@salk.edu \\ * Correspondence: bconti@scripps.edu; Tel.: +1-858-784-9069
}

Academic Editor: Donna Gruol

Received: 26 April 2016; Accepted: 2 June 2016; Published: 13 June 2016

\begin{abstract}
The cytokines interleukin 13 and 4 share a common heterodimeric receptor and are important modulators of peripheral allergic reactions. Produced primarily by T-helper type 2 lymphocytes, they are typically considered as anti-inflammatory cytokines because they can downregulate the synthesis of T-helper type 1 pro-inflammatory cytokines. Their presence and role in the brain is only beginning to be investigated and the data collected so far shows that these molecules can be produced by microglial cells and possibly by neurons. Attention has so far been given to the possible role of these molecules in neurodegeneration. Both neuroprotective or neurotoxic effects have been proposed based on evidence that interleukin 13 and 4 can reduce inflammation by promoting the M2 microglia phenotype and contributing to the death of microglia M1 phenotype, or by potentiating the effects of oxidative stress on neurons during neuro-inflammation. Remarkably, the heterodimeric subunit IL-13R $\alpha 1$ of their common receptor was recently demonstrated in dopaminergic neurons of the ventral tegmental area and the substantia nigra pars compacta, suggesting the possibility that both cytokines may affect the activity of these neurons regulating reward, mood, and motor coordination. In mice and man, the gene encoding for IL-13R $\alpha 1$ is expressed on the $X$ chromosome within the PARK12 region of susceptibility to Parkinson's disease (PD). This, together with finding that IL-13R $\alpha 1$ contributes to loss of dopaminergic neurons during inflammation, indicates the possibility that these cytokines may contribute to the etiology or the progression of PD.
\end{abstract}

Keywords: Interleukin 13; Interleukin 4; neuron; microglia; Parkinson; brain; neurodegeneration; neuroinflammation; neurotoxic; neuroprotection

\section{Introduction}

In this review we summarize the current body of knowledge on the role of IL-13 in the central nervous system. Although the study of this subject is in its infancy and only a limited amount of work has been done at this stage, it is likely that this will change in the near future. In fact, one of the interesting aspects of investigating the biology of IL-13 in the central nervous system (CNS) is that its canonical receptor, alpha type I (IL-13R $\alpha 1$ ), appears to be expressed not only in glial cells during pathological conditions, but also in specific subsets of neurons in the healthy brain. Specifically, IL-13R $\alpha 1$ has, so far, been found on dopaminergic neurons of the Substantia Nigra pars compacta (SNc) and the Ventral Tegmental Area (VTA) [1]. This finding indicates that its ligands, IL-13 and IL-4, could be important regulators of dopaminergic function and cell survival, and may provide a direct link between the immune system and the neurobiology of reward, addiction, or motor coordination.

\section{What We Know about IL-13 Comes from Studies of Its Biology in the Immune System}

The cytokines Interleukin 13 (IL-13) and interleukin-4 (IL-4) are two secreted proteins recognized for their role in promoting T-helper type 2 (Th2) lymphocyte-mediated allergic inflammation and 
atopy in the periphery [2-17]. IL-13 and IL-4 also have the ability to downregulate the synthesis of T-helper type 1 (Th1) lymphocyte pro-inflammatory cytokines: for this reason they are normally listed as anti-inflammatory interleukins [8-10,15,18-20]. Both cytokines are produced by Th2, as well as by other cell types, including eosinophils and basophils $[2,5,6,9,11-13]$ and IL-13 production is also stimulated in mast cells by lipopolysaccharides (LPS) [21-24].

IL-13 and IL-4 are often investigated together because they partially share a common receptor type: the IL-13 receptor alpha 1 chain (IL-13R $\alpha 1$ ). IL-13R $\alpha 1$ heterodimerizes with the IL-4R alpha chain (IL-4R $\alpha$ ) forming a complex capable of binding IL-13 or IL-4 (Figure 1) [25-32]. To date, this complex is the only known signal transducer for IL-13, while IL-4 can also signal through an IL-4R $\alpha /$ gamma chain complex. A high-affinity IL-13-binding protein (IL-13R $\alpha 2)$ also exists and is a specific inhibitor of IL-13 signaling, likely by functioning as a decoy receptor [28,33-36]. IL-13R $\alpha 2$ is not found in the healthy brain and, so far, has only been shown to be expressed in the CNS on glioblastoma cells [37] making it one of the major targets of immunotherapy. Work on IL-13R $\alpha 2$ in the CNS and its role as a therapeutic target will not be discussed here and is covered by recent excellent reviews [38].

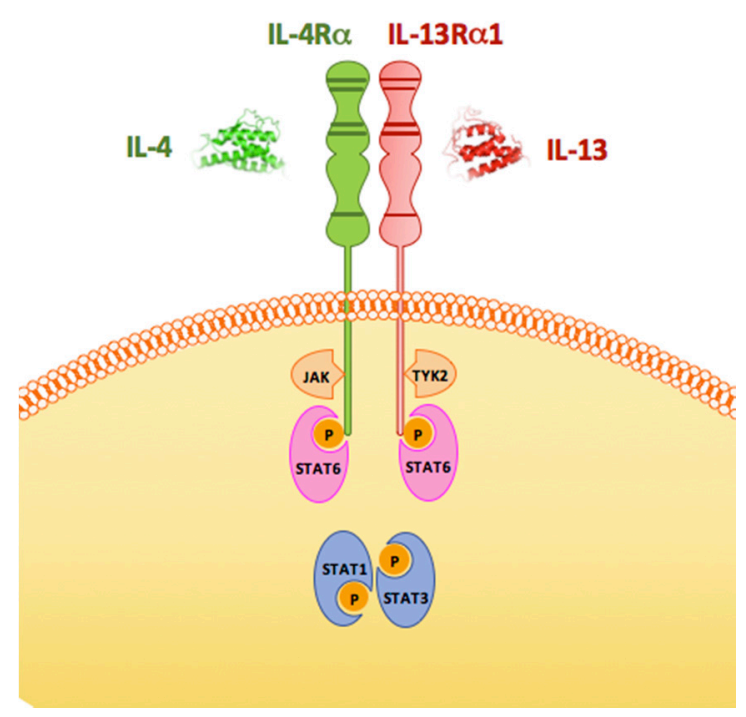

Figure 1. Schematic representation of the heterodimeric receptor for IL-13 and IL-4 and its signaling. Interleukins 13 (IL-13) and 4 (IL-4) can bind to the same heterodimeric receptor composed of the IL-13 Receptor alpha 1 (IL-13R $\alpha 1$ ) and the Interleukin 4 Receptor alpha (IL-4R $\alpha$ ). Binding of the receptor activates the Janus kinase (JAK) and leads to phosphorylation of members of the Signal Transducer and Activator of Transcription (STAT) family. The tyrosine-protein kinase 2 (TYK2) is a member of the JAK family. See the text for more details.

Binding of IL-13 to its cognate functional receptor allows the trans-phosphorylation of a specific tyrosine residue located in the Janus Kinase (JAK) activation segment $[31,39]$ which promotes the kinase activity required for the phosphorylation of downstream substrates in its signaling cascades $[39,40]$. IL-13 activates two intracellular signaling cascades: the JAK-STAT and the insulin receptor substrate (IRS)-phosphatidylinositol 3'-kinase pathways [26,28,31]. While the IRS-phosphatidylinositol 3'-kinase pathway leads to cell proliferation, the JAK-STAT pathway induces the transcription of genes that contain the Stat6-responsive enhancer element N6-GAS located in their promoter [41-43]. Upon activation of IL-13R $\alpha 1$, Stat1, 3, and 6 are phosphorylated and form a homodimer that migrates to the nucleus and binds to N6-GAS to drive transcription [31,42,44,45]. Reactive oxygen species (ROS) also play a role in the IL-13/IL-4 cellular transduction signaling. In intestinal epithelial cells upon IL-13R $\alpha 1$ activation both the JAK-STAT pathway and Mitogen Activated Protein Kinase (MAPK) stimulate nicotinamide adenine dinucleotide phosphate oxydase to produce intracellular ROS that, in a positive feedback loop, facilitate the phosphorylation of STAT6 and ERK [46]. 
Moreover, IL-13/IL-4-driven ROS production has been recently shown in alternatively-activated monocytes/macrophages through activation of monoamino oxydase A (MAO-A) [44].

\section{Expression of IL-13 and IL-4 in the CNS}

As mentioned above, IL-13 and IL-4 were demonstrated to be produced peripherally. To date, there is no evidence that these two proteins, both with molecular weights in the range of $15 \mathrm{kDa}$, can cross the blood-brain barrier. However, experimental work shows, instead, their local production in the CNS. Expression of IL-13 in the rodent brain was described in microglia, where its production was enhanced by peripheral injection of LPS or the neurotoxin 1-metil-4-fenil-1,2,3,6-tetraidropiridina (MPTP) [47-51].

Evidence also exists that both IL-13 and IL- 4 can be produced by neuronal cells of the hippocampus and the cortex in experimental models of ischemic insult [52,53]. In this context it has speculated that the production of IL-4 and IL-13, inducing alternative activation of microglia-known as the M2 state-can exert a protective effect against neuronal damage [53-55]. Neuronal production of IL-4 has been described lately in the noradrenergic neurons of the locus coeruleus, in which its release appears to be sensitive to behavioral stress [56]. Preliminary work in our laboratory also showed that IL-13 can be produced in neurons [57].

\section{What Is the Role of IL-13 and IL-4 in the CNS?}

Few studies have tested the effects of IL-13 and IL-4 in the CNS. Most of these have investigated a possible action on neuronal survival with some studies finding that IL-13 and/or IL-4 potentiate the effects of LPS and Interferon gamma (IFN-y), increasing oxidative damage and contributing to neuronal death [47-50,58-61]. On the other hand, other studies indicated that IL-13 and/or IL-4 could be neuroprotective either by directly reducing inflammation or by inducing the death of microglia cells that are considered to be cellular mediators of neuronal damage [47-50,59-65]. Notably, both IL-13 and IL-4 can potentiate LPS-induced sickness behavior when co-injected centrally with LPS, whereas only IL-4, and not IL-13, attenuates LPS-induced sickness behavior when administered several hours before LPS $[47,66]$. Recently, our laboratory collected evidence that IL-13 and IL-4 are not toxic when administered alone but can greatly increase the susceptibility of neurons to oxidative damage and contribute to their demise if they express IL-13R $\alpha 1$ [1].

\section{IL-13 and IL-4 in Multiple Sclerosis}

Multiple sclerosis (MS) is an autoimmune disorder affecting the CNS with a relapsing-remitting time course. IL-13 seems to exert a protective role in this context, as it is believed that in the development of the disease, a crucial role is played by the imbalance between pro-inflammatory cytokines (IL-1 $\beta$; TNF; INF- $\gamma$; IL-17) and anti-inflammatory cytokines (IL-4, IL-5, IL-10 and IL-13) $[67,68]$. IL-13 polymorphisms are associated with autoimmune diseases and also increase susceptibility to MS [69].

A study in humans with MS found that high levels of IL-13 in the cerebral spinal fluid (CSF) might exert a neuroprotective effect by enhancing Gamma Aminobuthirric Acid (GABA) over glutamate transmission [64]. Interestingly, an earlier report describes IL-4 having the same neural effect of increasing the GABA-induced inward current in neurons in a dose-dependent and reversible manner [70]. Moreover, the copolymer glatiramer acetate, an immunomodulatory drug currently used to treat MS, has shown to significantly increase the $\mathrm{TH}_{2}$ - lymphocyte production of IL-13 in patients [71].

Consistently, using the mouse experimental model of MS, experimental autoimmune encephalomyelitis (EAE), Cash and colleagues showed that IL-13 exerts its anti-inflammatory action by inactivating macrophages and reducing oxidative stress [72]. In the same model, an increase in circulating and spleen IL-13 prevented axonal injury [73] alone or in synergy with IL-4 [74], whereas IL-13 reduction was associated with loss of protection [75]. 
Sex difference can play a role in affecting the role of IL-13 in the MS model. While autoimmune diseases, including MS, are more common in women [76], the incidence and severity of EAE in mice, null for IL-13, was lower in females compared to males, suggesting the possibility that the contribution of IL-13 to EAE/MS may be gender specific [77]. To this end, it is interesting to note that the expression of IL-13 mRNA can be decreased by estrogen in a mouse model of inflammatory intestine disease [78] and that the gene encoding for IL-13R $\alpha 1$ is located on the $\mathrm{X}$ chromosome in both humans and mice.

Together, these studies suggest that IL-13 may have a neuroprotective role in MS. Although this may be different in other neurodegenerative diseases that, unlike MS, are not characterized by a severely-compromised blood-brain barrier, and are not primarily mediated by peripheral immune cells, IL-13 and IL-4 also showed protection in a mouse model of Alzheimer's disease (AD). Specifically, intracerebral injection of a mixture of IL-13 and IL-4 reduced amyloid deposition and improved spatial learning and memory in an AD transgenic mouse model when applied to young mice but did not show protective effects when administered in adult animals [79].

\section{Parkinson's Disease}

The IL-13 system may have a specific role in the pathogenesis and/or the progression of Parkinson's disease (PD). Data mining using the Online Mendelian Inheritance in Man (OMIM) database [80] showed that IL-13R $\alpha 1$ lies within the PARK12 region of susceptibility to PD. Although PARK12 comprises a large portion of DNA, it is located on the X chromosome, an observation that may be of interest in that PD has a higher incidence in men than in women. Even more intriguing was the finding that expression of IL-13R $\alpha 1$ in the brain appeared to be specific to the dopaminergic neurons of the VTA and of the SNc, the region affected by PD. Double-immunostaining studies also revealed that approximately $80 \%$ of the SNc neurons expressing the dopaminergic marker tyrosine hydroxylase also expressed IL-13R $\alpha 1$ [1].

The possible contribution of IL-13R $\alpha 1$ to neuronal fate was measured using a pro-inflammatory experimental mouse model of PD. Animals received periodic peripheral intraperitoneal injections of bacterial LPS over a period of six months, a regimen previously demonstrated to induce central loss of dopaminergic SNc neurons [81]. Comparative analysis showed that mice lacking IL-13R $\alpha 1$ were protected from neuronal loss when compared to their wild-type littermates, suggesting a neurotoxic action of its ligands, IL-13 and/or IL-4. In vitro experiments using a dopaminergic cell line showed, however, that neither IL-13 nor IL-4 had cytotoxic effects when administered alone. However, both cytokines increased the toxicity of non-toxic doses of oxidants in a dose-dependent manner.

Thus, activation of IL-13R $\alpha 1$ may be one of the mechanisms whereby the vulnerability of dopaminergic neurons is increased during inflammation, when both cytokines and ROS are produced. On the other hand, the lack of neurotoxicity of IL-13 or IL-4 in the absence of ROS suggests that these cytokines may be capable of regulating neuronal function by affecting the neurobiology of those neurons that participate in reward, addiction, and motor control.

Investigating these phenomena is likely to provide important information on the mechanisms of how IL-13 and IL-4 and, more generally, the immune system, may be capable of influencing behavior or can contribute to neurodegeneration.

\section{Conclusions}

Although in its infancy, the investigation of the central role of the interleukins 13 and 4 has is an exciting area of research. What makes it so attractive is that these two cytokines can be produced locally in the CNS and are active on both microglia and neuronal cells. Of special interest is the fact that they act through a common heterodimeric receptor that is expressed in dopaminergic neurons. Although these two Th2 cytokines are considered anti-inflammatory, studies conducted so far show that they can have cytotoxic effects on both glia and neurons. Interestingly these actions are not due to an intrinsic toxicity of IL-13 and IL-4 but rather to their ability to increase the cellular susceptibility to oxidative stress. This suggest that under pathological conditions, such as neuroinflammation when 
reactive oxygen species are produced, IL-13 and IL-4 can participate to tissue damage and thus to Parkinson's disease or other neurodegenerative disorders. Instead, under physiological conditions, these two cytokines can contribute to the regulation of neuronal function via direct action through neuronal IL-13R $\alpha 1$. Thus, they have the requisites of being potential neuromodulators.

Acknowledgments: Supported by the NIH (NS085155) and by The Michael J. Fox Foundation.

Author Contributions: S.M., P.M. and B.C. wrote the paper.

Conflicts of Interest: The authors declare no conflict of interest. The founding sponsors had no role in the design of the study; in the collection, analyses, or interpretation of data; in the writing of the manuscript, and in the decision to publish the results.

\section{References}

1. Morrison, B.E.; Marcondes, M.C.; Nomura, D.K.; Sanchez-Alavez, M.; Sanchez-Gonzalez, A.; Saar, I.; Kim, K.S.; Bartfai, T.; Maher, P.; Sugama, S.; et al. Cutting edge: IL-13R $\alpha 1$ expression in dopaminergic neurons contributes to their oxidative stress-mediated loss following chronic peripheral treatment with lipopolysaccharide. J. Immunol. 2012, 189, 5498-5502. [CrossRef] [PubMed]

2. Gibbs, B.F.; Haas, H.; Falcone, F.H.; Albrecht, C.; Vollrath, I.B.; Noll, T.; Wolff, H.H.; Amon, U. Purified human peripheral blood basophils release interleukin-13 and preformed interleukin-4 following immunological activation. Eur. J. Immunol. 1996, 26, 2493-2498. [CrossRef] [PubMed]

3. Haas, H.; Falcone, F.H.; Holland, M.J.; Schramm, G.; Haisch, K.; Gibbs, B.F.; Bufe, A.; Schlaak, M. Early interleukin-4: Its role in the switch towards a Th2 response and IgE-mediated allergy. Int. Arch. Allergy Immunol. 1999, 119, 86-94. [CrossRef] [PubMed]

4. Howard, M.; Paul, W.E. Interleukins for B lymphocytes. Lymphokine Res. 1982, 1, 1-4. [PubMed]

5. Jaffe, J.S.; Raible, D.G.; Post, T.J.; Wang, Y.; Glaum, M.C.; Butterfield, J.H.; Schulman, E.S. Human lung mast cell activation leads to IL-13 mRNA expression and protein release. Am. J. Respir. Cell Mol. Biol. 1996, 15, 473-481. [CrossRef] [PubMed]

6. Kim, E.Y.; Battaile, J.T.; Patel, A.C.; You, Y.; Agapov, E.; Grayson, M.H.; Benoit, L.A.; Byers, D.E.; Alevy, Y.; Tucker, J.; et al. Persistent activation of an innate immune response translates respiratory viral infection into chronic lung disease. Nat. Med. 2008, 14, 633-640. [CrossRef] [PubMed]

7. Lee, Y.C.; Lee, K.H.; Lee, H.B.; Rhee, Y.K. Serum levels of interleukins (IL)-4, IL-5, IL-13, and interferon-gamma in acute asthma. J. Asthma 2001, 38, 665-671. [CrossRef] [PubMed]

8. McKenzie, A.N.; Culpepper, J.A.; de Waal Malefyt, R.; Briere, F.; Punnonen, J.; Aversa, G.; Sato, A.; Dang, W.; Cocks, G.B.; Menon, S.; et al. Interleukin 13, a T-cell-derived cytokine that regulates human monocyte and B-cell function. Proc. Natl. Acad. Sci. USA 1993, 90, 3735-3739. [CrossRef] [PubMed]

9. Minty, A.; Chalon, P.; Derocq, J.M.; Dumont, X.; Guillemot, J.C.; Kaghad, M.; Labit, C.; Leplatois, P.; Liauzun, P.; Miloux, B.; et al. Interleukin-13 is a new human lymphokine regulating inflammatory and immune responses. Nature 1993, 362, 248-250. [CrossRef] [PubMed]

10. Morgan, J.G.; Dolganov, G.M.; Robbins, S.E.; Hinton, L.M.; Lovett, M. The selective isolation of novel cDNAs encoded by the regions surrounding the human interleukin 4 and 5 genes. Nucleic Acids Res. 1992, 20, 5173-5179. [CrossRef] [PubMed]

11. Ochensberger, B.; Daepp, G.C.; Rihs, S.; Dahinden, C.A. Human blood basophils produce interleukin-13 in response to IgE-receptor-dependent and -independent activation. Blood 1996, 88, 3028-3037. [PubMed]

12. Reglier, H.; Arce-Vicioso, M.; Fay, M.; Gougerot-Pocidalo, M.A.; Chollet-Martin, S. Lack of IL-10 and IL-13 production by human polymorphonuclear neutrophils. Cytokine 1998, 10, 192-198. [CrossRef] [PubMed]

13. Schmid-Grendelmeier, P.; Altznauer, F.; Fischer, B.; Bizer, C.; Straumann, A.; Menz, G.; Blaser, K.; Wuthrich, B.; Simon, H.U. Eosinophils express functional IL-13 in eosinophilic inflammatory diseases. J. Immunol. 2002, 169, 1021-1027. [CrossRef] [PubMed]

14. Silvestri, M.; Bontempelli, M.; Giacomelli, M.; Malerba, M.; Rossi, G.A.; Di Stefano, A.; Rossi, A.; Ricciardolo, F.L. High serum levels of tumour necrosis factor- $\alpha$ and interleukin- 8 in severe asthma: Markers of systemic inflammation? Clin. Exp. Allergy 2006, 36, 1373-1381. [CrossRef] [PubMed]

15. Wills-Karp, M.; Luyimbazi, J.; Xu, X.; Schofield, B.; Neben, T.Y.; Karp, C.L.; Donaldson, D.D. Interleukin-13: Central mediator of allergic asthma. Science 1998, 282, 2258-2261. [CrossRef] [PubMed] 
16. Wong, C.K.; Ho, C.Y.; Ko, F.W.; Chan, C.H.; Ho, A.S.; Hui, D.S.; Lam, C.W. Proinflammatory cytokines (IL-17, IL-6, IL-18 and IL-12) and Th cytokines (IFN-gamma, IL-4, IL-10 and IL-13) in patients with allergic asthma. Clin. Exp. Immunol. 2001, 125, 177-183. [CrossRef] [PubMed]

17. Wynn, T.A. IL-13 effector functions. Annu. Rev. Immunol. 2003, 21, 425-456. [CrossRef] [PubMed]

18. Brown, K.D.; Zurawski, S.M.; Mosmann, T.R.; Zurawski, G. A family of small inducible proteins secreted by leukocytes are members of a new superfamily that includes leukocyte and fibroblast-derived inflammatory agents, growth factors, and indicators of various activation processes. J. Immunol. 1989, 142, 679-687. [PubMed]

19. Kuperman, D.A.; Schleimer, R.P. Interleukin-4, interleukin-13, signal transducer and activator of transcription factor 6, and allergic asthma. Curr. Mol. Med. 2008, 8, 384-392. [CrossRef] [PubMed]

20. Wills-Karp, M. Interleukin-13 in asthma pathogenesis. Immunol. Rev. 2004, 202, 175-190. [CrossRef] [PubMed]

21. Chiba, N.; Masuda, A.; Yoshikai, Y.; Matsuguchi, T. Ceramide inhibits LPS-induced production of IL-5, IL-10, and IL-13 from mast cells. J. Cell. Physiol. 2007, 213, 126-136. [CrossRef] [PubMed]

22. Galli, S.J.; Gordon, J.R.; Wershil, B.K. Cytokine production by mast cells and basophils. Curr. Opin. Immunol. 1991, 3, 865-872. [CrossRef]

23. Masuda, A.; Yoshikai, Y.; Aiba, K.; Matsuguchi, T. Th2 cytokine production from mast cells is directly induced by lipopolysaccharide and distinctly regulated by c-Jun $\mathrm{N}$-terminal kinase and p38 pathways. J. Immunol. 2002, 169, 3801-3810. [CrossRef] [PubMed]

24. Supajatura, V.; Ushio, H.; Nakao, A.; Okumura, K.; Ra, C.; Ogawa, H. Protective roles of mast cells against enterobacterial infection are mediated by Toll-like receptor 4. J. Immunol. 2001, 167, 2250-2256. [CrossRef] [PubMed]

25. Aman, M.J.; Tayebi, N.; Obiri, N.I.; Puri, R.K.; Modi, W.S.; Leonard, W.J. cDNA cloning and characterization of the human interleukin 13 receptor $\alpha$ chain. J. Biol. Chem. 1996, 271, 29265-29270. [PubMed]

26. Callard, R.E.; Matthews, D.J.; Hibbert, L. IL-4 and IL-13 receptors: Are they one and the same? Immunol. Today 1996, 17, 108-110. [CrossRef]

27. Hilton, D.J.; Zhang, J.G.; Metcalf, D.; Alexander, W.S.; Nicola, N.A.; Willson, T.A. Cloning and characterization of a binding subunit of the interleukin 13 receptor that is also a component of the interleukin 4 receptor. Proc. Natl. Acad. Sci. USA 1996, 93, 497-501. [CrossRef] [PubMed]

28. Jiang, H.; Harris, M.B.; Rothman, P. IL-4/IL-13 signaling beyond JAK/STAT. J. Allergy Clin. Immunol. 2000, 105 Pt 1, 1063-1070. [CrossRef] [PubMed]

29. Leonard, W.J.; O'Shea, J.J. Jaks and STATs: Biological implications. Annu. Rev. Immunol. 1998, 16, $293-322$. [CrossRef] [PubMed]

30. Lin, J.X.; Migone, T.S.; Tsang, M.; Friedmann, M.; Weatherbee, J.A.; Zhou, L.; Yamauchi, A.; Bloom, E.T.; Mietz, J.; John, S.; et al. The role of shared receptor motifs and common Stat proteins in the generation of cytokine pleiotropy and redundancy by IL-2, IL-4, IL-7, IL-13, and IL-15. Immunity 1995, 2, 331-339. [CrossRef]

31. Nelms, K.; Keegan, A.D.; Zamorano, J.; Ryan, J.J.; Paul, W.E. The IL-4 receptor: Signaling mechanisms and biologic functions. Annu. Rev. Immunol. 1999, 17, 701-738. [CrossRef] [PubMed]

32. Orchansky, P.L.; Ayres, S.D.; Hilton, D.J.; Schrader, J.W. An interleukin (IL)-13 receptor lacking the cytoplasmic domain fails to transduce IL-13-induced signals and inhibits responses to IL-4. J. Biol. Chem. 1997, 272, 22940-22947. [CrossRef] [PubMed]

33. Caput, D.; Laurent, P.; Kaghad, M.; Lelias, J.M.; Lefort, S.; Vita, N.; Ferrara, P. Cloning and characterization of a specific interleukin (IL)-13 binding protein structurally related to the IL-5 receptor $\alpha$ chain. J. Biol. Chem. 1996, 271, 16921-16926. [PubMed]

34. Donaldson, D.D.; Whitters, M.J.; Fitz, L.J.; Neben, T.Y.; Finnerty, H.; Henderson, S.L.; O’Hara, R.M., Jr.; Beier, D.R.; Turner, K.J.; Wood, C.R.; et al. The murine IL-13 receptor $\alpha$ 2: Molecular cloning, characterization, and comparison with murine IL-13 receptor $\alpha$ 1. J. Immunol. 1998, 161, 2317-2324. [PubMed]

35. Feng, N.; Lugli, S.M.; Schnyder, B.; Gauchat, J.F.; Graber, P.; Schlagenhauf, E.; Schnarr, B.; Wiederkehr-Adam, M.; Duschl, A.; Heim, M.H.; et al. The interleukin-4/interleukin-13 receptor of human synovial fibroblasts: Overexpression of the nonsignaling interleukin-13 receptor $\alpha 2$. Lab. Investig. 1998, 78, 591-602. [PubMed] 
36. Liu, H.; Jacobs, B.S.; Liu, J.; Prayson, R.A.; Estes, M.L.; Barnett, G.H.; Barna, B.P. Interleukin-13 sensitivity and receptor phenotypes of human glial cell lines: Non-neoplastic glia and low-grade astrocytoma differ from malignant glioma. Cancer Immunol. Immunother. 2000, 49, 319-324. [CrossRef] [PubMed]

37. Debinski, W.; Gibo, D.M.; Hulet, S.W.; Connor, J.R.; Gillespie, G.Y. Receptor for interleukin 13 is a marker and therapeutic target for human high-grade gliomas. Clin. Cancer Res. 1999, 5, 985-990. [PubMed]

38. Sengupta, S.; Thaci, B.; Crawford, A.C.; Sampath, P. Interleukin-13 receptor $\alpha$ 2-targeted glioblastoma immunotherapy. Biomed. Res. Int. 2014, 2014, 952128. [CrossRef] [PubMed]

39. Haque, S.J.; Wu, Q.; Kammer, W.; Friedrich, K.; Smith, J.M.; Kerr, I.M.; Stark, G.R.; Williams, B.R. Receptor-associated constitutive protein tyrosine phosphatase activity controls the kinase function of JAK1. Proc. Natl. Acad. Sci. USA 1997, 94, 8563-8568. [CrossRef] [PubMed]

40. Johnson, L.N.; Noble, M.E.; Owen, D.J. Active and inactive protein kinases: Structural basis for regulation. Cell 1996, 85, 149-158. [CrossRef]

41. Hou, J.; Schindler, U.; Henzel, W.J.; Ho, T.C.; Brasseur, M.; McKnight, S.L. An interleukin-4-induced transcription factor: IL-4 Stat. Science 1994, 265, 1701-1706. [CrossRef] [PubMed]

42. Mikita, T.; Campbell, D.; Wu, P.; Williamson, K.; Schindler, U. Requirements for interleukin-4-induced gene expression and functional characterization of Stat6. Mol. Cell. Biol. 1996, 16, 5811-5820. [CrossRef] [PubMed]

43. Schindler, U.; Wu, P.; Rothe, M.; Brasseur, M.; McKnight, S.L. Components of a Stat recognition code: Evidence for two layers of molecular selectivity. Immunity 1995, 2, 689-697. [CrossRef]

44. Bhattacharjee, A.; Shukla, M.; Yakubenko, V.P.; Mulya, A.; Kundu, S.; Cathcart, M.K. IL-4 and IL-13 employ discrete signaling pathways for target gene expression in alternatively activated monocytes/macrophages. Free Radic. Biol. Med. 2013, 54, 1-16. [CrossRef] [PubMed]

45. Darnell, J.E., Jr.; Kerr, I.M.; Stark, G.R. Jak-STAT pathways and transcriptional activation in response to IFNs and other extracellular signaling proteins. Science 1994, 264, 1415-1421. [CrossRef] [PubMed]

46. Mandal, D.; Fu, P.; Levine, A.D. REDOX regulation of IL-13 signaling in intestinal epithelial cells: Usage of alternate pathways mediates distinct gene expression patterns. Cell. Signal. 2010, 22, 1485-1494. [CrossRef] [PubMed]

47. Bluthe, R.M.; Bristow, A.; Lestage, J.; Imbs, C.; Dantzer, R. Central injection of interleukin-13 potentiates LPS-induced sickness behavior in rats. Neuroreport 2001, 12, 3979-3983. [CrossRef] [PubMed]

48. Shin, W.H.; Lee, D.Y.; Park, K.W.; Kim, S.U.; Yang, M.S.; Joe, E.H.; Jin, B.K. Microglia expressing interleukin-13 undergo cell death and contribute to neuronal survival in vivo. Glia 2004, 46, 142-152. [CrossRef] [PubMed]

49. Yang, M.-S.; Ji, K.-A.; Jeon, S.-B.; Jin, B.-K.; Kim, S.U.; Jou, N.; Joe, E. Interleukin-13 enhances cyclooxygenase-2 expression in activated rat brain microglia: Implications for death of activated microglia. J. Immunol. 2006, 177, 1323-1329. [CrossRef] [PubMed]

50. Yang, M.S.; Park, E.J.; Sohn, S.; Kwon, H.J.; Shin, W.H.; Pyo, H.K.; Jin, B.; Choi, K.S.; Jou, I.; Joe, E.H. Interleukin-13 and -4 induce death of activated microglia. Glia 2002, 38, 273-280. [CrossRef] [PubMed]

51. Yasuda, Y.; Shimoda, T.; Uno, K.; Tateishi, N.; Furuya, S.; Yagi, K.; Suzuki, K.; Fujita, S. The effects of MPTP on the activation of microglia/astrocytes and cytokine/chemokine levels in different mice strains. J. Neuroimmunol. 2008, 204, 43-51. [CrossRef] [PubMed]

52. Yu, J.T.; Lee, C.H.; Yoo, K.Y.; Choi, J.H.; Li, H.; Park, O.K.; Yan, B.; Hwang, I.K.; Kwon, Y.G.; Kim, Y.M.; et al. Maintenance of anti-inflammatory cytokines and reduction of glial activation in the ischemic hippocampal CA1 region preconditioned with lipopolysaccharide. J. Neurol. Sci. 2010, 296, 69-78. [CrossRef] [PubMed]

53. Zhao, X.; Wang, H.; Sun, G.; Zhang, J.; Edwards, N.J.; Aronowski, J. Neuronal interleukin-4 as a modulator of microglial pathways and ischemic brain damage. J. Neurosci. 2015, 35, 11281-11291. [CrossRef] [PubMed]

54. Latta, C.H.; Sudduth, T.L.; Weekman, E.M.; Brothers, H.M.; Abner, E.L.; Popa, G.J.; Mendenhall, M.D.; Gonzalez-Oregon, F.; Braun, K.; Wilcock, D.M. Determining the role of IL-4 induced neuroinflammation in microglial activity and amyloid- $\beta$ using BV2 microglial cells and APP/PS1 transgenic mice. J. Neuroinflamm. 2015, 12, 41. [CrossRef] [PubMed]

55. Xiong, X.; Xu, L.; Wei, L.; White, R.E.; Ouyang, Y.B.; Giffard, R.G. IL-4 is required for sex differences in vulnerability to focal ischemia in mice. Stroke 2015, 46, 2271-2276. [CrossRef] [PubMed]

56. Lee, H.J.; Park, H.J.; Starkweather, A.; An, K.; Shim, I. Decreased interleukin-4 release from the neurons of the Locus Coeruleus in response to immobilization stress. Med. Inflamm. 2016, 2016, 3501905. [CrossRef] [PubMed]

57. Conti, B. The Scripps Research Institute, CA, USA. Unpublished work, 2016. 
58. Nam, J.H.; Park, K.W.; Park, E.S.; Lee, Y.B.; Lee, H.G.; Baik, H.H.; Kim, Y.S.; Maeng, S.; Park, J.; Jin, B.K. Interleukin-13/-4-induced oxidative stress contributes to death of hippocampal neurons in a $\beta 1$-42-treated hippocampus in vivo. Antioxid. Redox Signal. 2012, 16, 1369-1383. [CrossRef] [PubMed]

59. Park, K.W.; Baik, H.H.; Jin, B.K. Interleukin-4-induced oxidative stress via microglial NADPH oxidase contributes to the death of hippocampal neurons in vivo. Curr. Aging Sci. 2008, 1, 192-201. [CrossRef] [PubMed]

60. Park, K.W.; Baik, H.H.; Jin, B.K. IL-13-induced oxidative stress via microglial NADPH oxidase contributes to death of hippocampal neurons in vivo. J. Immunol. 2009, 183, 4666-4674. [CrossRef] [PubMed]

61. Yadav, M.C.; Burudi, E.M.; Alirezaei, M.; Flynn, C.C.; Watry, D.D.; Lanigan, C.M.; Fox, H.S. IFN-gamma-induced IDO and WRS expression in microglia is differentially regulated by IL-4. Glia 2007, 55, 1385-1396. [CrossRef] [PubMed]

62. Clarke, R.M.; Lyons, A.; O'Connell, F.; Deighan, B.F.; Barry, C.E.; Anyakoha, N.G.; Nicolaou, A.; Lynch, M.A. A pivotal role for interleukin-4 in atorvastatin-associated neuroprotection in rat brain. J. Biol. Chem. 2008, 283, 1808-1817. [CrossRef] [PubMed]

63. Deboy, C.A.; Xin, J.; Byram, S.C.; Serpe, C.J.; Sanders, V.M.; Jones, K.J. Immune-mediated neuroprotection of axotomized mouse facial motoneurons is dependent on the IL-4/STAT6 signaling pathway in CD4(+) T cells. Exp. Neurol. 2006, 201, 212-224. [CrossRef] [PubMed]

64. Rossi, S.; Mancino, R.; Bergami, A.; Mori, F.; Castelli, M.; De Chiara, V.; Studer, V.; Mataluni, G.; Sancesario, G.; Parisi, V.; et al. Potential role of IL-13 in neuroprotection and cortical excitability regulation in multiple sclerosis. Mult. Scler. J. 2011, 17, 1301-1312. [CrossRef] [PubMed]

65. Won, S.Y.; Kim, S.R.; Maeng, S.; Jin, B.K. Interleukin-13/Interleukin-4-induced oxidative stress contributes to death of prothrombinkringle-2 (pKr-2)-activated microglia. J. Neuroimmunol. 2013, 265, 36-42. [CrossRef] [PubMed]

66. Bluthe, R.M.; Lestage, J.; Rees, G.; Bristow, A.; Dantzer, R. Dual effect of central injection of recombinant rat interleukin-4 on lipopolysaccharide-induced sickness behavior in rats. Neuropsychopharmacology 2002, 26, 86-93. [CrossRef]

67. Linker, R.A.; Sendtner, M.; Gold, R. Mechanisms of axonal degeneration in EAE-Lessons from CNTF and MHC I knockout mice. J. Neurol. Sci. 2005, 233, 167-172. [CrossRef] [PubMed]

68. Zeis, T.; Graumann, U.; Reynolds, R.; Schaeren-Wiemers, N. Normal-appearing white matter in multiple sclerosis is in a subtle balance between inflammation and neuroprotection. Brain 2008, 131, 288-303. [CrossRef] [PubMed]

69. Seyfizadeh, N.; Kazemi, T.; Farhoudi, M.; Reza Aliparasti, M.; Sadeghi-Bazargani, H.; Almasi, S.; Babaloo, Z. Association of IL-13 single nucleotide polymorphisms in Iranian patients to multiple sclerosis. Am. J. Clin. Exp. Immunol. 2014, 3, 124-129. [PubMed]

70. Rozsa, K.S.; Rubakhin, S.S.; Szucs, A.; Hughes, T.K.; Stefano, G.B. Opposite effects of interleukin-2 and interleukin-4 on GABA-induced inward currents of dialysed lymnaea neurons. Gen. Pharmacol. 1997, 29, 73-77. [CrossRef]

71. Sanna, A.; Fois, M.L.; Arru, G.; Huang, Y.M.; Link, H.; Pugliatti, M.; Rosati, G.; Sotgiu, S. Glatiramer acetate reduces lymphocyte proliferation and enhances IL-5 and IL-13 production through modulation of monocyte-derived dendritic cells in multiple sclerosis. Clin. Exp. Immunol. 2006, 143, 357-362. [CrossRef] [PubMed]

72. Cash, E.; Minty, A.; Ferrara, P.; Caput, D.; Fradelizi, D.; Rott, O. Macrophage-inactivating IL-13 suppresses experimental autoimmune encephalomyelitis in rats. J. Immunol. 1994, 153, 4258-4267. [PubMed]

73. Offner, H.; Subramanian, S.; Wang, C.; Afentoulis, M.; Vandenbark, A.A.; Huan, J.; Burrows, G.G. Treatment of passive experimental autoimmune encephalomyelitis in SJL mice with a recombinant TCR ligand induces IL-13 and prevents axonal injury. J. Immunol. 2005, 175, 4103-4111. [CrossRef] [PubMed]

74. Young, D.A.; Lowe, L.D.; Booth, S.S.; Whitters, M.J.; Nicholson, L.; Kuchroo, V.K.; Collins, M. IL-4, IL-10, IL-13, and TGF- $\beta$ from an altered peptide ligand-specific Th2 cell clone down-regulate adoptive transfer of experimental autoimmune encephalomyelitis. J. Immunol. 2000, 164, 3563-3572. [CrossRef] [PubMed]

75. Ochoa-Repáraz, J.; Rynda, A.; Ascón, M.A.; Yang, X.; Kochetkova, I.; Riccardi, C.; Callis, G.; Trunkle, T.; Pascual, D.W. IL-13 production by regulatory $\mathrm{T}$ cells protects against experimental autoimmune encephalomyelitis independently of autoantigen. J. Immunol. 2008, 181, 954-968. [CrossRef] [PubMed]

76. Compston, A.; Coles, A. Multiple sclerosis. Lancet 2008, 372, 1502-1517. [CrossRef] 
77. Sinha, S.; Kaler, L.J.; Proctor, T.M.; Teuscher, C.; Vandenbark, A.A.; Offner, H. IL-13-mediated gender difference in susceptibility to autoimmune encephalomyelitis. J. Immunol. (Baltim. Md. 1950) 2008, 180, 2679-2685. [CrossRef]

78. Verdu, E.F.; Deng, Y.; Bercik, P.; Collins, S.M. Modulatory effects of estrogen in two murine models of experimental colitis. Am. J. Physiol. Gastrointest. Liver Physiol. 2002, 283, 27-36. [CrossRef] [PubMed]

79. Kawahara, K.; Suenobu, M.; Yoshida, A.; Koga, K.; Hyodo, A.; Ohtsuka, H.; Kuniyasu, A.; Tamamaki, N.; Sugimoto, Y.; Nakayama, H. Intracerebral microinjection of interleukin-4/interleukin-13 reduces $\beta$-amyloid accumulation in the ipsilateral side and improves cognitive deficits in young amyloid precursor protein 23 mice. Neuroscience 2012, 207, 243-260. [CrossRef] [PubMed]

80. Man (OMIM) database. Available online: http:/ / www.omim.org (accessed on 9 June 2016).

81. Frank-Cannon, T.C.; Tran, T.; Ruhn, K.A.; Martinez, T.N.; Hong, J.; Marvin, M.; Hartley, M.; Trevino, I.; O'Brien, D.E.; Casey, B.; et al. Parkin deficiency increases vulnerability to inflammation-related nigral degeneration. J. Neurosci. 2008, 28, 10825-10834. [CrossRef] [PubMed]

(C) 2016 by the authors; licensee MDPI, Basel, Switzerland. This article is an open access article distributed under the terms and conditions of the Creative Commons Attribution (CC-BY) license (http://creativecommons.org/licenses/by/4.0/). 